\title{
Characteristics and Formation Mechanism of Surface Ozone in a Coastal Island of Southeast China: Influence of Sea-land Breezes and Regional Transport
}

\author{
Baoye Hu${ }^{1,2,3}$, Taotao Liu ${ }^{1,2,3}$, Yuxiang Yang ${ }^{4}$, Youwei Hong ${ }^{1,2 *}$, Mengren $\mathrm{Li}^{1,2}$, Lingling $\mathrm{Xu}^{1,2}$, \\ Hong Wang ${ }^{5}$, Naihua Chen ${ }^{4}$, Xin Wu ${ }^{1,2,3}$, Jinsheng Chen ${ }^{1,2^{*}}$ \\ ${ }^{1}$ Center for Excellence in Regional Atmospheric Environment, Institute of Urban Environment, Chinese Academy of \\ Sciences, Xiamen 361021, China \\ ${ }^{2}$ Key Lab of Urban Environment and Health, Institute of Urban Environment, Chinese Academy of Sciences, Xiamen \\ 361021, China \\ ${ }^{3}$ University of Chinese Academy of Sciences, Beijing 100086, China \\ ${ }^{4}$ Pingtan Environmental Monitoring Center of Fujian, Pingtan 350400, China \\ ${ }^{5}$ Fujian Meteorological Science Institute, Fuzhou 350001, China
}

\begin{abstract}
The ozone $\left(\mathrm{O}_{3}\right)$ concentrations in island cities are low due to the relatively low concentrations of $\mathrm{O}_{3}$ precursors. However, Pingtan, a typical island city along the southeast coast of China, suffers from frequent $\mathrm{O}_{3}$ pollution. In this study, one year of hourly $\mathrm{O}_{3}$ concentration data collected from three sites (rural, suburban, and urban) on Pingtan were used to investigate the characteristics and formation mechanism of $\mathrm{O}_{3}$ pollution. The results showed that the minimum $\mathrm{O}_{3}$ concentrations measured at the three sites were larger than $55.53 \mu \mathrm{g} \mathrm{m}^{-3}$, which was likely caused by low NO titration over Pingtan. The $\mathrm{O}_{3}$ concentrations in summer were low because of the East Asian monsoon. The daily maximum $\mathrm{O}_{3}$ concentrations with sea and land breezes (SLBs) were higher than those without SLBs at all three sites (8.52, 9.84, and $14.30 \mu \mathrm{g} \mathrm{m}^{-3}$ at the rural, suburban, and urban sites, respectively). In addition, SLBs amplified the diurnal variation in $\mathrm{O}_{3}$ concentrations. Cluster analysis and the analysis of an episode of high $\mathrm{O}_{3}$ concentration indicated that the developed Yangtze River Delta is the main source of $\mathrm{O}_{3}$ in Pingtan. This study helps reveal the characteristics and formation mechanism of $\mathrm{O}_{3}$ pollution in island cities.
\end{abstract}

Keywords: Ozone $\left(\mathrm{O}_{3}\right)$; Spatiotemporal variation; Transport; Sea and land breezes; Island.

\section{INTRODUCTION}

Surface ozone $\left(\mathrm{O}_{3}\right)$ is a key component of photochemical smog and is harmful to public health, vegetation (NRC, 1991), and crop yield (Lal et al., 2017). Strict emission measures enacted in the 1990s have alleviated serious $\mathrm{O}_{3}$ pollution in many European and American urban areas (Simon et al., 2015; Lin et al., 2017). Meanwhile, rapid urbanization and industrialization have taken place in South and East Asia, resulting in significant increases in the anthropogenic emissions of $\mathrm{O}_{3}$ precursors (Duncan et al., 2015) and possibly shifting global hot spots of air pollution to these densely populated regions (Zhang et al., 2016). The number of photochemical studies focused on

\footnotetext{
* Corresponding authors.

Tel./Fax: +86-592-6190765

E-mail address: jschen@iue.ac.cn (J. Chen);

ywhong@iue.ac.cn (Y. Hong)
}

the mainland of China has increased substantially since 2005, especially in the Beijing-Tianjin-Hebei (BTH) region, the Pearl River Delta (PRD) region, and the Yangtze River Delta (YRD) region (Wang et al., 2017). However, the number of photochemical studies focused on island cities are limited.

Generally, the meteorological conditions of island cities are complex and are easily affected by sea and land breezes (SLBs). SLBs play important roles in $\mathrm{O}_{3}$ distribution and concentration in island cities (Hsu and Cheng, 2019). For example, Wang et al. (2018) demonstrated that $\mathrm{O}_{3}$ episodes can be affected by SLBs. Ding et al. (2004) used MM5, a mesoscale model, to simulate SLBs-related $\mathrm{O}_{3}$ episode. Using the WRF-CHEM model, Bei et al. (2018) found that land breeze transports pollutants from the inland to coastal areas, causing $\mathrm{O}_{3}$ episodes over the gulf, while sea breeze recirculates the pollutants, aggravating air pollution over the gulf. Studying SLBs is helpful to understand the interactions between continental and marine atmospheres. To the best of our knowledge, few studies have investigated the effects of SLBs on islands of southeast China. 
Therefore, the effects of SLBs on $\mathrm{O}_{3}$ concentration in subtropical monsoon climates are not clear, severely limiting our understanding of the interactions between continental and oceanic air masses. An island with minimal contributions from local emissions is ideal for studying the effect of regional transport on $\mathrm{O}_{3}$ pollution.

Pingtan, a southeast coastal island of China, has low levels of primary pollutant emissions but high $\mathrm{O}_{3}$ concentrations. Pingtan has a population of only 0.42 million, a land area of $371.91 \mathrm{~km}^{2}$, and a sea area of $6,064 \mathrm{~km}^{2}$. Despite having no major industries, the annual average $\mathrm{O}_{3}$ concentration in Pingtan is 1.5 to 2.5 times higher than those of other cities in Fujian Province (Wang et al., 2018). Wind speed in this region is relatively high throughout the year because of the "narrow tube effect" in the Taiwan Strait. Excluding typhoon weather, the maximum wind speed in Pingtan is $30-40 \mathrm{~m} \mathrm{~s}^{-1}$ at $10 \mathrm{~m}$ above ground. Since the influence of local pollutants in Pingtan is minimal, Pingtan is easily affected by long-distance transport. Comparing field studies on the atmospheric environment in regions with low primary pollutant emissions with those in regions with high primary pollutant emissions can provide important information about the effects of human activities and improve our understanding of $\mathrm{O}_{3}$ pollution in those regions.

Given the limited number of studies on $\mathrm{O}_{3}$ levels conducted on islands along with the urban focus of existing studies, $\mathrm{O}_{3}$ levels on Pingtan were measured at three sites (rural, suburban, and urban) to better represent the geographical features of $\mathrm{O}_{3}$. First, the spatiotemporal variations in $\mathrm{O}_{3}$ levels were evaluated based on field measurements. Second, the effects of SLBs on $\mathrm{O}_{3}$ concentration and its diurnal variations were explored. Finally, the effects of regional transport on $\mathrm{O}_{3}$ pollution in Pingtan were discussed.

\section{METHODOLOGY}

\section{Study Area}

Pingtan, which is located in Southeast China and has a subtropical climate, is one of the five largest islands in China. The annual average precipitation and temperature are $1196.2 \mathrm{~mm}$ and $19.5^{\circ} \mathrm{C}$, respectively. As shown on the left side of Fig. 1, Pingtan is located in the Taiwan Strait. Due to the "narrow tube effect" of the Taiwan Strait, the annual average wind speed of Pingtan is $8 \mathrm{~m} \mathrm{~s}^{-1}$ at $10 \mathrm{~m}$ above ground. Therefore, Pingtan is easily affected by regional transport. Pingtan is also affected by SLBs, as indicated by data collected by the Pingtan Ocean Observation Station (POOS). Thus, we choose Pingtan as a site to study the effects of regional transport and SLBs on $\mathrm{O}_{3}$ concentration. Unlike the Pingtan Weather Station, POOS is located on the eastern coastline of Pingtan, which is less affected by topography and adverse environmental factors. The location of POOS is indicated by the star symbol on the right side of Fig. 1. Based on the $\mathrm{O}_{3}$ data available for January to December 2015, the following three air quality monitoring stations in different areas of Pingtan were

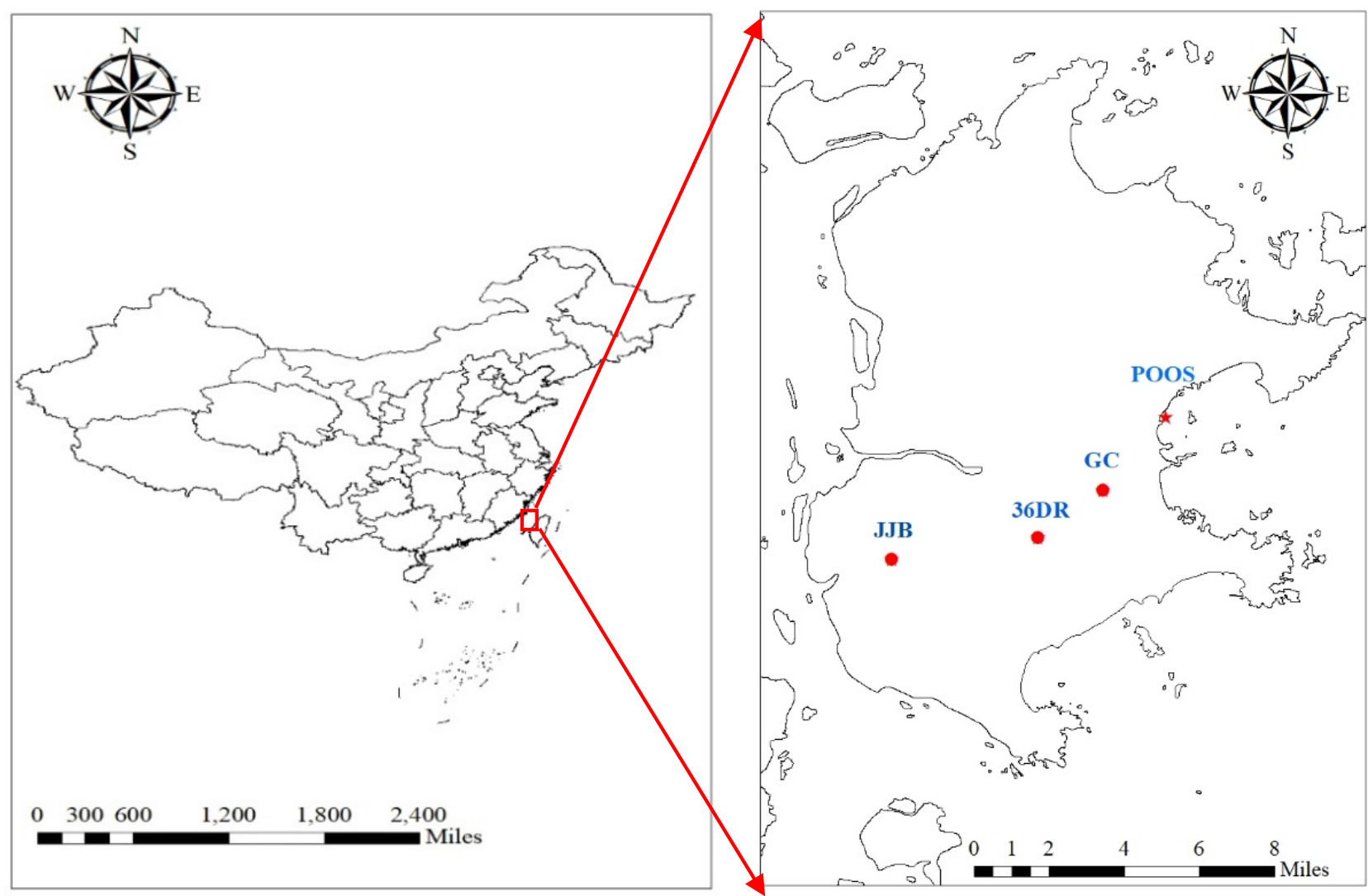

Fig. 1. Location of Pingtan in China (left) and locations of the three monitoring sites and the Pingtan Ocean Observation Station (POOS) in Pingtan (right). 
selected for this study: (1) 36-Degree Reservoir (36DR), a rural site, is situated in the center of Pingtan and is surrounded by forests and lakes; (2) Jinjing Bay (JJB), a suburban site, is located in the southwestern region of Pingtan and is a developing area with considerable ongoing construction; and (3) Government of County (GC), an urban site, is located in downtown Pingtan and is surrounded by the main road, which has a high volume of motor vehicles. The locations of the monitoring sites (round symbols) are also presented on the right side of Fig. 1.

\section{Collection and Analysis of $\mathrm{O}_{3}$ Data and Other Parameters}

The air pollution data recorded in Pingtan from January to December 2015 [local time (UTC+8)] included hourly average concentrations of $\mathrm{O}_{3}, \mathrm{NO}_{\mathrm{x}}, \mathrm{CO}, \mathrm{SO}_{2}, \mathrm{PM}_{10}$, and $\mathrm{PM}_{2.5}$. Meteorological parameters were also collected from each site.

The surface $\mathrm{O}_{3}$ concentration was measured using an ultraviolet spectrophotometric ozone analyzer (Thermo Model 49i). The concentrations of $\mathrm{NO}_{2}$ and $\mathrm{NO}$ were measured using a $\mathrm{NO}-\mathrm{NO}_{2}-\mathrm{NO}_{\mathrm{x}}$ analyzer based on chemiluminescence (Thermo Model 42i). The CO concentration was measured based on the absorption of infrared radiation (Thermo Model 48i). The $\mathrm{SO}_{2}$ concentration was determined by a pulse fluorescence $\mathrm{SO}_{2}$ analyzer (Thermo Model 43i). These instruments were automatically calibrated on a daily basis using a dynamic gas calibrator (TE 146C). The $\mathrm{PM}_{2.5}$ (SHARP 5030) and $\mathrm{PM}_{10}$ (FH62C14) concentrations were measured using $\beta$-ray methods. Meteorological parameters were determined continuously by microwave induction measurements using a Lufft WS500-UMB Compact Weather Station.

The eight-hour maximum concentrations of $\mathrm{O}_{3}$ on mainland China from October 10-17, 2015, were downloaded from datacenter.mep.gov.cn/ (in Chinese). The data used to calculate the trajectories from January to December 2015 were downloaded from the Air Resources Laboratory (ARL) of the National Oceanic and Atmospheric Administration (NOAA) (ftp://arlftp.arlhq.noaa.gov./pub/archives/gdas1).

\section{Analysis of Trajectories}

To identify the sources of air parcels reaching the monitoring sites, the atmospheric trajectory was studied through backward trajectory analysis. The three-day backward trajectories were computed at an elevation of $500 \mathrm{~m}$ above the center of Pingtan $\left(119.78^{\circ} \mathrm{E}, 25.51^{\circ} \mathrm{N}\right)$ from 00:00 to 23:00 (UTC) throughout 2015. This 72-h time scale is appropriate for capturing the long-distance transport of air pollutants because the majority of pollutants fall within a few days. The elevation of $500 \mathrm{~m}$ ensures that the atmospheric boundary layer is the origin of the backward trajectories (Latif et al., 2012). The Hybrid Single Particle Lagrangian Integrated Trajectory model (HYSPLIT, version 4), which was developed by the NOAA ARL (Rolph, 2003), was used to calculate the backward trajectories. To compare the origins of air masses between different months, the clustering method was applied to cluster the obtained trajectories according to transport characteristics, length, and curvature. Data for the entire year were used to compare the $\mathrm{O}_{3}$ concentrations of different clustering trajectories. The HYSPLIT model and Ward method were used for cluster analysis (Romesburg, 1984). The algorithm minimizes the total spatial variance (TSV), where the spatial variance of the cluster is the sum of the squared distances between the endpoints of the trajectory (Stunder, 1996). The TSV plot is applied to determine the cut-off point of the algorithm and the optimal cluster number based on the detection of a sharp increase in the TSV plot. A sharp increase in TSV indicates the combination various clusters. Thus, the clustering algorithm should be ended at this moment (Eva and Lambin, 1998).

\section{Potential Source Contribution Function (PSCF) Analysis}

PSCF analysis is a statistical method to assess the contributions of certain air masses to observed pollutant concentrations that exceed a given threshold (Hopke et al., 1995). In this study, PSCF values were computed to distinguish potential source zones contributing to the high concentrations of $\mathrm{O}_{3}$ and $\mathrm{CO}$ in Pingtan. The study area was split into $i \times j$ small cells of equal size. The PSCF values were normalized using the following equation:

$P S C F_{i j}=n_{i j} / m_{i j}$

where $\mathrm{n}_{i j}$ is the number of endpoints included in the $i j^{\text {th }}$ cell with pollutant concentration above a given threshold, and $\mathrm{m}_{i j}$ is the total number of endpoints for the $i j^{\text {th }}$ cell. Cells with high PSCF values are associated with air masses in which a pollutant exceeds the threshold value. This suggests that the corresponding regions are potential contributors to receptor contamination.

A total of 5,184 72-h backward trajectory endpoints (3 d $\times 72 \mathrm{~h} \times 24 \mathrm{~h}$ ) were used in this study. The PSCFs were calculated within a defined area $\left(25^{\circ} \mathrm{N}, 80^{\circ} \mathrm{E}\right.$ to $58^{\circ} \mathrm{N}$, $130^{\circ} \mathrm{E}$ ) comprising 6,600 grid cells with latitude/longitude dimensions of $0.5^{\circ} \times 0.5^{\circ}$. Thus, the mean number of endpoints per cell $\left(n_{\text {ave }}\right)$ was $5,184 / 6,600 \cong 1$. The average concentration of each pollutant from October 12-14, 2015 was evaluated with respect to the threshold criteria. The PSCF values were multiplied by an arbitrary weighting function $W_{i j}$ (Polissar et al., 1999) to reduce uncertainty in cells with $n_{i j} \leq 3 n_{a v e}$. $W_{i j}$ was determined as follows:

$$
W_{i j}=\left\{\begin{array}{ll}
1.00 & n_{i j}>3 n_{a v e} \\
0.70 & 1.5 n_{a v e}<n_{i j} \leq 3 n_{a v e} \\
0.42 & n_{a v e}<n_{i j} \leq 1.5 n_{a v e} \\
0.17 & n_{i j} \leq n_{a v e}
\end{array}\right\} .
$$

\section{RESULTS AND DISCUSSION}

\section{General Characteristics of $\mathrm{O}_{3}$ Concentration}

The $\mathrm{O}_{3}$ concentrations in Pingtan were 67.5, 66.2, and $79.2 \mathrm{\mu g} \mathrm{m}^{-3}$ at the urban, suburban, and rural sites, respectively (Table 1). Compared to the concentrations of $\mathrm{O}_{3}$ at the other two sites, the $\mathrm{O}_{3}$ concentration at the rural site was significantly higher, likely due to the lack of NO 
Table 1. Comparison of annual average $\mathrm{O}_{3}$ concentrations determined in this study with those reported elsewhere.

\begin{tabular}{|c|c|c|c|c|}
\hline Location & Site type & Time & $\mathrm{O}_{3}\left(\mu \mathrm{g} \mathrm{m}^{-3}\right)$ & Reference \\
\hline Anantapur, India & Rural & Jan.-Dec. 2010 & 87.2 & (Reddy et al., 2012) \\
\hline New Jersey, USA & Urban & Jun. 2007-May 2008 & 46.9 & (Roberts-Semple et al., 2012) \\
\hline \multirow[t]{4}{*}{ Andalusia, Spain } & Urban (traffic) & $2003-2008$ & 51.0 & (Adame et al., 2014) \\
\hline & Urban background & $2003-2008$ & 55.9 & \\
\hline & Suburban background & $2003-2008$ & 66.0 & \\
\hline & Rural background & $2003-2008$ & 72.0 & \\
\hline \multirow[t]{3}{*}{ Delhi, India } & Urban background & 2013-2014 & 68.1 & (Kumar et al., 2014) \\
\hline & Urban (traffic) & 2013-2014 & 62.4 & \\
\hline & Rural & 2013-2014 & 84.4 & \\
\hline Seoul, Korea & Urban & 2013 & 42.2 & (Vellingiri et al., 2016) \\
\hline Shanghai, China & Urban & 2015 & 55.5 & (Gao et al., 2017) \\
\hline \multirow[t]{2}{*}{ Guangzhou, China } & Urban & 2007 & 38.6 & (Zheng et al., 2010) \\
\hline & Suburban & 2007 & 57.9 & \\
\hline Huizhou, China & Rural & 2007 & 81.4 & \\
\hline Hongkong, China & coastal & 2007 & 47.1 & \\
\hline Nanjing, China & Urban & Jan. 2000-Feb. 2003 & 43.7 & (Tu et al., 2007) \\
\hline \multirow[t]{3}{*}{ Ningbo, China } & Urban & $2012-2015$ & 48.6 & (Tong et al., 2017) \\
\hline & Suburban & & 77.4 & \\
\hline & Rural & & 80.8 & \\
\hline Zhoushan, China & Rural & Apr--Oct. 2015 & 91.71 & (Tong et al., 2018) \\
\hline \multirow[t]{3}{*}{ Pingtan, China } & Urban & Jan.-Dec. 2015 & 67.5 & Present study \\
\hline & Suburban & Jan.-Dec. 2015 & 66.2 & \\
\hline & Rural & Jan.-Dec. 2015 & 79.2 & \\
\hline
\end{tabular}

If concentration in other articles was reported in $\mathrm{ppb}$, it was converted into $\mu \mathrm{g} \mathrm{m}^{-3}$ using the following formula: concentration $\left(\mu \mathrm{g} \mathrm{m}^{-3}\right)=$ concentration $(\mathrm{ppbv}) \times 48 / 22.4$.

titration at the rural site (Kiros et al., 2017; Kulkarni et al., 2017). The annual mean $\mathrm{O}_{3}$ concentration in Pingtan was compared to the concentrations reported for other cities (Table 1). The $\mathrm{O}_{3}$ concentration at the urban site on Pingtan island $\left(67.5 \mu \mathrm{g} \mathrm{m}^{-3}\right)$ was similar to the urban background concentration reported in Delhi $\left(68.1 \mu \mathrm{g} \mathrm{m}^{-3}\right)$ but obviously higher than those observed in the urban areas of New Jersey $\left(46.9 \mu \mathrm{g} \mathrm{m}^{-3}\right)$, Andalusia $\left(51.0 \mu \mathrm{g} \mathrm{m}^{-3}\right)$, Shanghai $\left(55.5 \mu \mathrm{g} \mathrm{m}^{-3}\right)$, Guangzhou $\left(38.6 \mu \mathrm{g} \mathrm{m}^{-3}\right)$, Nanjing (43.7 $\left.\mu \mathrm{g} \mathrm{m}^{-3}\right)$, Ningbo $\left(48.6 \mu \mathrm{g} \mathrm{m}^{-3}\right)$, and Seoul $\left(42.2 \mu \mathrm{g} \mathrm{m}^{-3}\right)$ along with Andalusia $\left(55.9 \mu \mathrm{g} \mathrm{m}^{-3}\right)$. The $\mathrm{O}_{3}$ at these urban sites with high traffic density might be consumed by NO titration from traffic emissions. The concentration of $\mathrm{O}_{3}$ at the suburban site on Pingtan island $\left(66.2 \mu \mathrm{g} \mathrm{m}^{-3}\right)$ was nearly equal to that of the suburban background of Andalusia $\left(66.0 \mu \mathrm{g} \mathrm{m}^{-3}\right)$, approximately $8.3 \mu \mathrm{g} \mathrm{m}^{-3}$ higher than that reported for Guangzhou, and approximately $11.2 \mu \mathrm{g} \mathrm{m}^{-3}$ lower than that reported for Ningbo. The $\mathrm{O}_{3}$ concentration at the rural site of Pingtan $\left(79.2 \mu \mathrm{g} \mathrm{m}^{-3}\right)$ was similar to those reported for rural sites in other locations (Zheng et al., 2010; Reddy et al., 2012; Kumar et al., 2014; Tong et al., 2017). However, the $\mathrm{O}_{3}$ concentration of the rural site of Zhoushan $\left(91.71 \mu \mathrm{g} \mathrm{m}^{-3}\right)$, which has few commercial and residential buildings nearby and similar climatic conditions to Pingtan, was much higher than that of the rural site of Pingtan (Tong et al., 2018). This can be attributed to the fact that Zhoushan is located in the YRD and is easily affected by the YRD. However, Pingtan is affected by YRD in the condition of regional transport. Overall, the $\mathrm{O}_{3}$ concentration at the urban site of Pingtan, an island in
Southeast China with few anthropogenic activities, was higher than those reported for metropolitan areas.

Diurnal variations in pollutant concentrations provide insights into the interactions between emissions and daily chemical/physical processes. Fig. 2(a) presents the mean annual variations in diurnal $\mathrm{O}_{3}$ concentration. $\mathrm{O}_{3}$ concentration began to increase after 08:00 and peaked at 15:00-16:00 at all three monitoring sites. This trend was opposite that observed for $\mathrm{NO}_{2}$ in the daytime (Fig. S1). This phenomenon suggests that $\mathrm{NO}_{2}$ was mainly transformed into $\mathrm{O}_{3}$ in the daytime (Khoder, 2009; Hassan et al., 2013). The maximum $\mathrm{O}_{3}$ concentrations at the rural, suburban, and urban sites were 93.29, 79.09, and $77.18 \mu \mathrm{g} \mathrm{m}^{-3}$, respectively. The $\mathrm{O}_{3}$ concentration at the rural site was obviously higher than those at the urban and suburban sites, and the diurnal $\mathrm{O}_{3}$ maximum appeared one hour later at rural site compared to at the other two sites. Among the three sites, the $\mathrm{O}_{3}$ concentration was highest at the rural site, which can be explained as follows. The air masses transported from the urban site, upwind of the rural site, had high concentrations of $\mathrm{O}_{3}$ precursors. These air masses led to elevated levels of $\mathrm{O}_{3}$ over the rural site, which was characterized by low NO titration (Banan et al., 2013). The rural site is located in an area that is protected for drinking water, and anthropogenic sources of pollution such as vehicle exhaust and industrial emission are few. Therefore, the NO concentration was low at the rural site $\left(0.51 \mu \mathrm{g} \mathrm{m}^{-3}\right)$. The delayed time of peak $\mathrm{O}_{3}$ concentration at the rural site compared with the other two sites indicates that the photochemically aged plume is a key source of $\mathrm{O}_{3}$ at the rural site (Xu et al., 2011). The minimum 

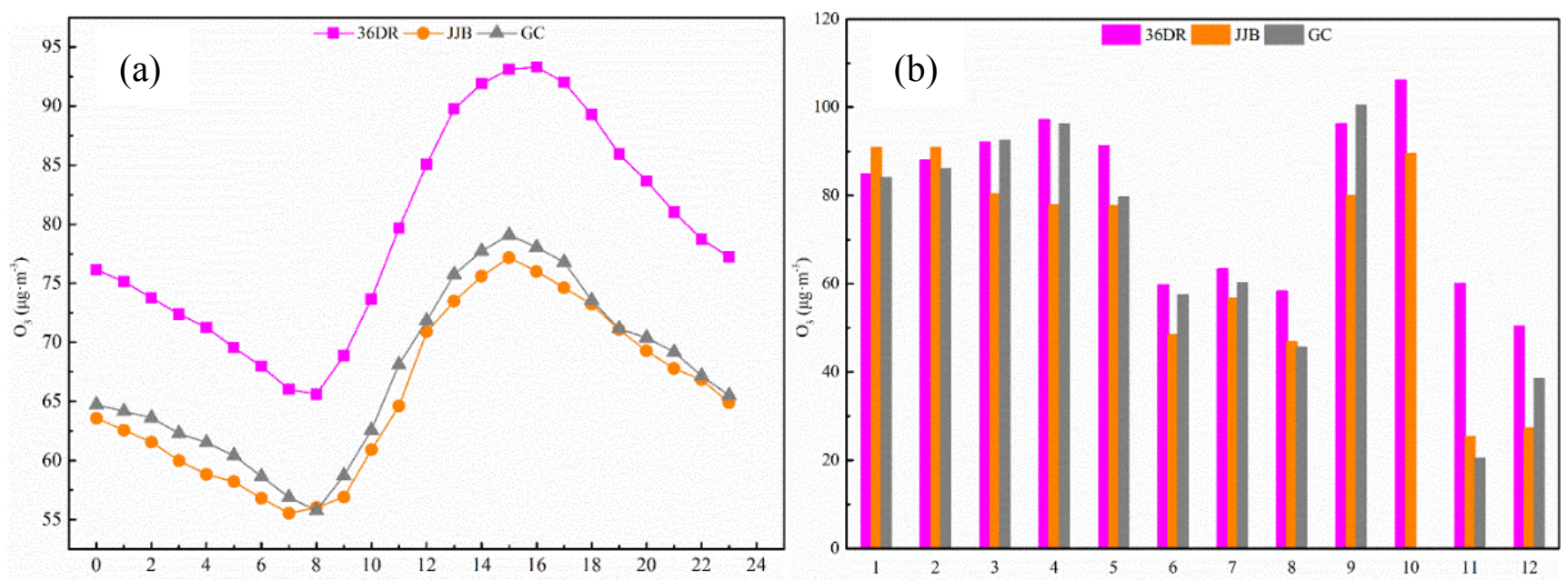

Fig. 2. (a) Diurnal variations in $\mathrm{O}_{3}$ concentration and (b) monthly variation in $\mathrm{O}_{3}$ concentration for the three monitoring sites.

$\mathrm{O}_{3}$ concentrations measured at the rural $\left(65.60 \mu \mathrm{g} \mathrm{m}^{-3}\right)$, suburban $\left(55.77 \mu \mathrm{g} \mathrm{m}^{-3}\right)$, and urban sites $\left(55.53 \mu \mathrm{g} \mathrm{m}^{-3}\right)$ were higher than those reported in other cities, which was likely caused by low NO titration over the three sites in this study. The NO concentrations for the rural and the urban sites were only 0.51 and $1.63 \mu \mathrm{g} \mathrm{m}^{-3}$, respectively. Unfortunately, the NO data for the suburban site were invalid.

The $\mathrm{O}_{3}$ concentrations in Pingtan were higher in spring (March, April, and May) and early autumn (September and October) compared to in summer (June, July, and August; Fig. 2(c)). This seasonal trend is widespread at mid-latitudes in the northern hemisphere (Monks, 2000). Notably, the seasonal variations in $\mathrm{O}_{3}$ concentration in Pingtan are consistent with those reported for PRD, Taipei, and Japan (Chou et al., 2006), which are located in the East Asian monsoon region. The maximum concentration of $\mathrm{O}_{3}$ was observed in the spring due to the transport of air masses over long distances from contaminated areas on the continent (Gong et al., 2018). The minimum $\mathrm{O}_{3}$ concentration was observed in summer, which is attributed to the transport of air masses with relatively low $\mathrm{O}_{3}$ concentrations from the ocean (Pochanart et al., 1999; Chou et al., 2006; Latif et al., 2012). Fig. S2 shows the monthly mean 72-h backward trajectory cluster along with the contribution of each trajectory cluster to the total trajectory cluster. All clusters in June, July, and August are from the ocean, which might explain why the $\mathrm{O}_{3}$ concentration was low in the summer. The relatively rainy weather in the summer might also contribute to this phenomenon by restricting $\mathrm{O}_{3}$ formation, which requires solar radiation, and accelerating $\mathrm{O}_{3}$ removal via wet deposition (Jo and Park, 2005; Tong et al., 2017). The precipitation in summer was significantly higher than in the other three seasons; the precipitation amounts in spring, summer, autumn, and winter were 82.53, 176.90, 88.86 , and $75.93 \mathrm{~mm}$, respectively.

\section{Effect of SLBs on $\mathrm{O}_{3}$}

SLBs is a mesoscale local circulation system caused by the difference of thermal power between land and sea. SLBs are key area of research related to the atmospheric boundary layer in coastal regions. The mesoscale circulation caused by SLBs is directly related to the diffusion and transport of atmospheric pollutants in coastal cities (Wagner et al., 2012). Therefore, SLBs play important roles in the distribution of $\mathrm{O}_{3}$ concentration in island cities (Wang et al., 2018). In this study, SLBs were considered to be present when the absolute value of variation in wind direction between approximately 02:00 and 14:00 ranged from $90^{\circ}$ to $270^{\circ}$, and both sea breeze and land breeze lasted for longer than $3 \mathrm{~h}$. The sea breeze always blows in the daytime, while land breeze occurs in the evening. SLBs are driven by temperature differences between land and sea along with topographic conditions, and SLBs usually occurs when the winds are weak (Lu et al., 2009; Wang et al., 2018). As shown in Table 2, SLBs were recorded on 44 days in Pingtan in 2015, including two days of pollution. The month with the maximum number of days with SLBs (eight days) was March followed by May (six days), January, February, April, August, and November (four days each), July and October (three days), September (two days), and June and December (one day). The daily mean wind speed fluctuated between 1.2 and $7.4 \mathrm{~m} \mathrm{~s}^{-1}$. As shown in Fig. 3, the maximum daily $\mathrm{O}_{3}$ concentration was always higher with SLBs than without SLBs at the three sites (8.52, 9.84, and $14.30 \mu \mathrm{g} \mathrm{m}^{-3}$ for the rural, suburban, and urban sites, respectively). When SLBs occurred, the wind speed was lower than when SLBs were absent; this lower wind speed is conducive to the accumulation of $\mathrm{O}_{3}$, resulting in a higher $\mathrm{O}_{3}$ concentration. The analysis of observational data combined with simulations using the WRF-CHEM model indicated that SLBs promoted the accumulation of $\mathrm{O}_{3}$, resulting in the deterioration of air quality (Bei et al., 2018). Hsu and Cheng (2019) applied cluster analysis also finding that SLBs were favorable to $\mathrm{O}_{3}$ accumulation.

The diurnal variations in $\mathrm{O}_{3}$ concentration with and without SLBs were inconsistent (Fig. 4). On days without SLBs, the differences between the minimum and maximum 
Table 2. Number of days with SLBs each month.

\begin{tabular}{|c|c|c|c|c|c|c|c|}
\hline $\begin{array}{l}\text { Number } \\
\text { of days }\end{array}$ & Month & Day & $\begin{array}{l}\text { Nighttime } \\
\text { wind direction }\end{array}$ & $\begin{array}{l}\text { Daytime } \\
\text { wind } \\
\text { direction }\end{array}$ & $\begin{array}{l}\text { Daily average wind } \\
\text { speed (00-23 hour) } \\
\left(\mathrm{m} \mathrm{s}^{-1}\right)\end{array}$ & $\begin{array}{l}\text { Time when the } \\
\text { land breeze turns } \\
\text { to sea breeze }\end{array}$ & $\begin{array}{l}\text { Time when the } \\
\text { sea breeze turns } \\
\text { to land breeze }\end{array}$ \\
\hline \multirow[t]{4}{*}{4} & 1 & 4 & NNW & SE & 2.5 & $10^{\mathrm{h}}$ & $19^{\mathrm{h}}$ \\
\hline & 1 & 5 & NW & $\mathrm{E}$ & 1.2 & $12^{\mathrm{h}}$ & $22^{\mathrm{h}}$ \\
\hline & 1 & 21 & NW & $\mathrm{E}$ & 2.1 & $11^{\mathrm{h}}$ & $21^{\mathrm{h}}$ \\
\hline & 1 & 26 & SSW & ENE & 2.3 & $11^{\mathrm{h}}$ & $22^{\mathrm{h}}$ \\
\hline 4 & 2 & $11-14$ & SW & $\mathrm{E}$ & 1.8 & $12^{\mathrm{h}}$ & $22^{\mathrm{h}}$ \\
\hline \multirow[t]{7}{*}{8} & 3 & 3 & $\mathrm{~W}$ & $\mathrm{E}$ & 5.3 & $13^{h}$ & $00^{\mathrm{h}}$ \\
\hline & 3 & 9 & $\mathrm{~W}$ & $\mathrm{NE}$ & 7.4 & $06^{\mathrm{h}}$ & - \\
\hline & 3 & $14-15$ & NW & $\mathrm{NE}$ & 3.3 & $04^{\mathrm{h}}$ & $22^{\mathrm{h}}$ \\
\hline & 3 & 17 & $\mathrm{~N}$ & SSE & 2.5 & $11^{\mathrm{h}}$ & $00^{\mathrm{h}}$ \\
\hline & 3 & 19 & WSW & NNE & 6.6 & $11^{\mathrm{h}}$ & - \\
\hline & 3 & 27 & NNW & ESE & 3.6 & $09^{\mathrm{h}}$ & - \\
\hline & 3 & 30 & NNW & ESE & 2.6 & $08^{\mathrm{h}}$ & $19^{\mathrm{h}}$ \\
\hline \multirow[t]{4}{*}{4} & 4 & 5 & WSW & SSE & 3.4 & $05^{\mathrm{h}}$ & $20^{\mathrm{h}}$ \\
\hline & 4 & 6 & WSW & NNE & 6.8 & $04^{\mathrm{h}}$ & - \\
\hline & 4 & 13 & SW & ENE & 3.3 & $10^{\mathrm{h}}$ & $19^{\mathrm{h}}$ \\
\hline & 4 & 27 & $\mathrm{~N}$ & ESE & 3.4 & $09^{\mathrm{h}}$ & $22^{\mathrm{h}}$ \\
\hline \multirow[t]{6}{*}{6} & 5 & 3 & SW & $\mathrm{E}$ & 3.3 & $12^{\mathrm{h}}$ & - \\
\hline & 5 & 9 & SW & $\mathrm{NE}$ & 4.7 & $14^{\mathrm{h}}$ & $00^{\mathrm{h}}$ \\
\hline & 5 & 11 & $\mathrm{~N}$ & ESE & 3.7 & $09^{\mathrm{h}}$ & $20^{\mathrm{h}}$ \\
\hline & 5 & 12 & WNW & $\mathrm{E}$ & 5.0 & $09^{\mathrm{h}}$ & $21^{\mathrm{h}}$ \\
\hline & 5 & 13 & NNW & SSE & 2.7 & $08^{\mathrm{h}}$ & $22^{\mathrm{h}}$ \\
\hline & 5 & 31 & WSW & $\mathrm{NE}$ & 4.7 & $09^{\mathrm{h}}$ & $03^{\mathrm{h}}$ \\
\hline 1 & 6 & 1 & $\mathrm{~N}$ & SSE & 3.4 & $08^{\mathrm{h}}$ & $19^{\mathrm{h}}$ \\
\hline \multirow[t]{3}{*}{3} & 7 & 15 & $\mathrm{~N}$ & ESE & 2.6 & $07^{\mathrm{h}}$ & $23^{\mathrm{h}}$ \\
\hline & 7 & 16 & $\mathrm{~N}$ & ESE & 3.3 & $07^{\mathrm{h}}$ & $19^{\mathrm{h}}$ \\
\hline & 7 & 25 & SW & ENE & 4.9 & $13^{\mathrm{h}}$ & $22^{\mathrm{h}}$ \\
\hline \multirow[t]{4}{*}{4} & 8 & 5 & $\mathrm{~N}$ & ESE & 2.8 & $09^{\mathrm{h}}$ & $20^{\mathrm{h}}$ \\
\hline & 8 & 13 & WSW & $\mathrm{E}$ & 4.4 & $08^{\mathrm{h}}$ & - \\
\hline & 8 & 17 & SW & ESE & 3.2 & $10^{\mathrm{h}}$ & $19^{\mathrm{h}}$ \\
\hline & 8 & 25 & NNW & SE & 2.8 & $04^{\mathrm{h}}$ & $01^{\mathrm{h}}$ \\
\hline \multirow[t]{2}{*}{2} & 9 & 2 & WSW & SE & 2.0 & $13^{\mathrm{h}}$ & $23^{\mathrm{h}}$ \\
\hline & 9 & 24 & WNW & $\mathrm{NE}$ & 5.3 & $11^{\mathrm{h}}$ & $23^{\mathrm{h}}$ \\
\hline \multirow[t]{3}{*}{3} & 10 & 8 & NNW & SE & 3.3 & $12^{\mathrm{h}}$ & $20^{\mathrm{h}}$ \\
\hline & 10 & 27 & WNW & $\mathrm{SE}$ & 3.5 & $10^{\mathrm{h}}$ & $05^{\mathrm{h}}$ \\
\hline & 10 & 30 & SW & NNE & 7.1 & $11^{\mathrm{h}}$ & - \\
\hline \multirow[t]{4}{*}{4} & 11 & 7 & $\mathrm{~N}$ & ESE & 3.0 & $12^{\mathrm{h}}$ & $20^{\mathrm{h}}$ \\
\hline & 11 & 8 & NNW & SE & 1.8 & $08^{\mathrm{h}}$ & $00^{\mathrm{h}}$ \\
\hline & 11 & 13 & $\mathrm{~N}$ & SSE & 3.4 & $10^{\mathrm{h}}$ & $23^{\mathrm{h}}$ \\
\hline & 11 & 17 & NW & WSW & 1.9 & $10^{\mathrm{h}}$ & $21^{\mathrm{h}}$ \\
\hline 1 & 12 & 23 & WSW & $\mathrm{E}$ & 3.3 & $11^{\mathrm{h}}$ & $19^{\mathrm{h}}$ \\
\hline
\end{tabular}

Note: "h" in Table 2 means hour.

$\mathrm{O}_{3}$ concentrations were $24.59,20.77$, and $20.63 \mu \mathrm{g} \mathrm{m}^{-3}$ at the rural, suburban, and urban sites, respectively. In contrast, larger differences between the minimum and maximum $\mathrm{O}_{3}$ concentrations were observed on days with SLBs (47.50, 28.71, and $47.47 \mu \mathrm{g} \mathrm{m}^{-3}$ at the rural, suburban, and urban sites, respectively). Sea breeze, which always occurs after sunrise, brings cold and moist air from over the ocean into contact with hot and dry air over land. This results in a thermal interior boundary layer over coastal land and produces an inversion near the convergence line between sea and land breezes. Atmospheric stratification is relatively stable due to the inversion, resulting in weakened convective motion; these conditions are not conductive to $\mathrm{O}_{3}$ diffusion (Stauffer et al., 2015). In addition, sea breeze carries polluted air masses over the sea, which aggravates the cycle of pollution between the sea and inland (Darby et al., 2007). SLBs form in the absence of large-scale weather systems, which further makes the atmosphere calm. Therefore, in the absence of SLBs, the $\mathrm{O}_{3}$ concentration was primarily affected by regional transport. In contrast, in the presence of SLBs, local photochemical reactions were dominant in $\mathrm{O}_{3}$ formation. The suburban Pingtan site experienced high winds throughout the year; thus, SLBs had little influence at this site. 


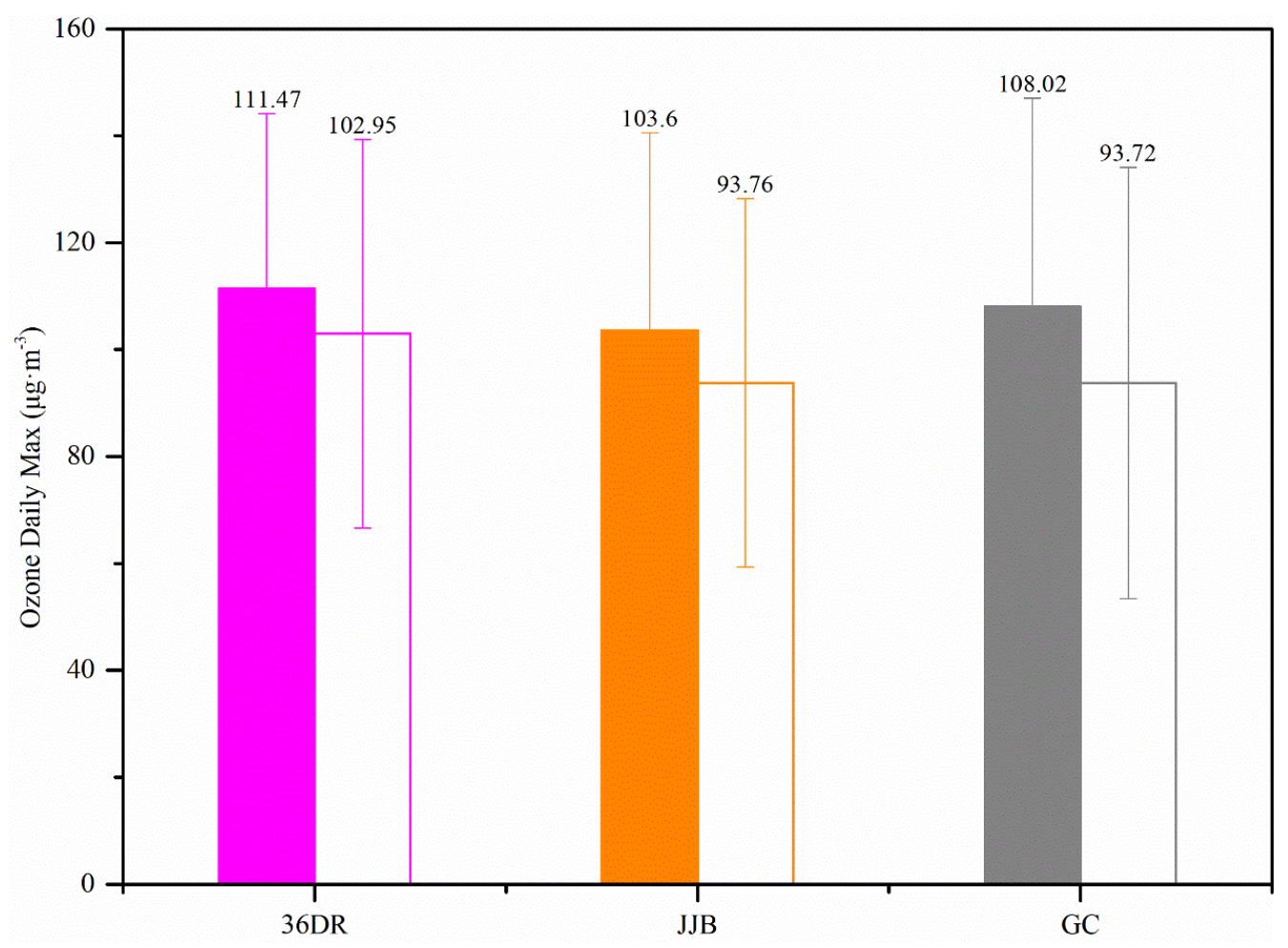

Fig. 3. Differences in $\mathrm{O}_{3}$ concentration between days with SLBs (solid columns) and days without SLBs (hollow columns) at the three monitoring sites.

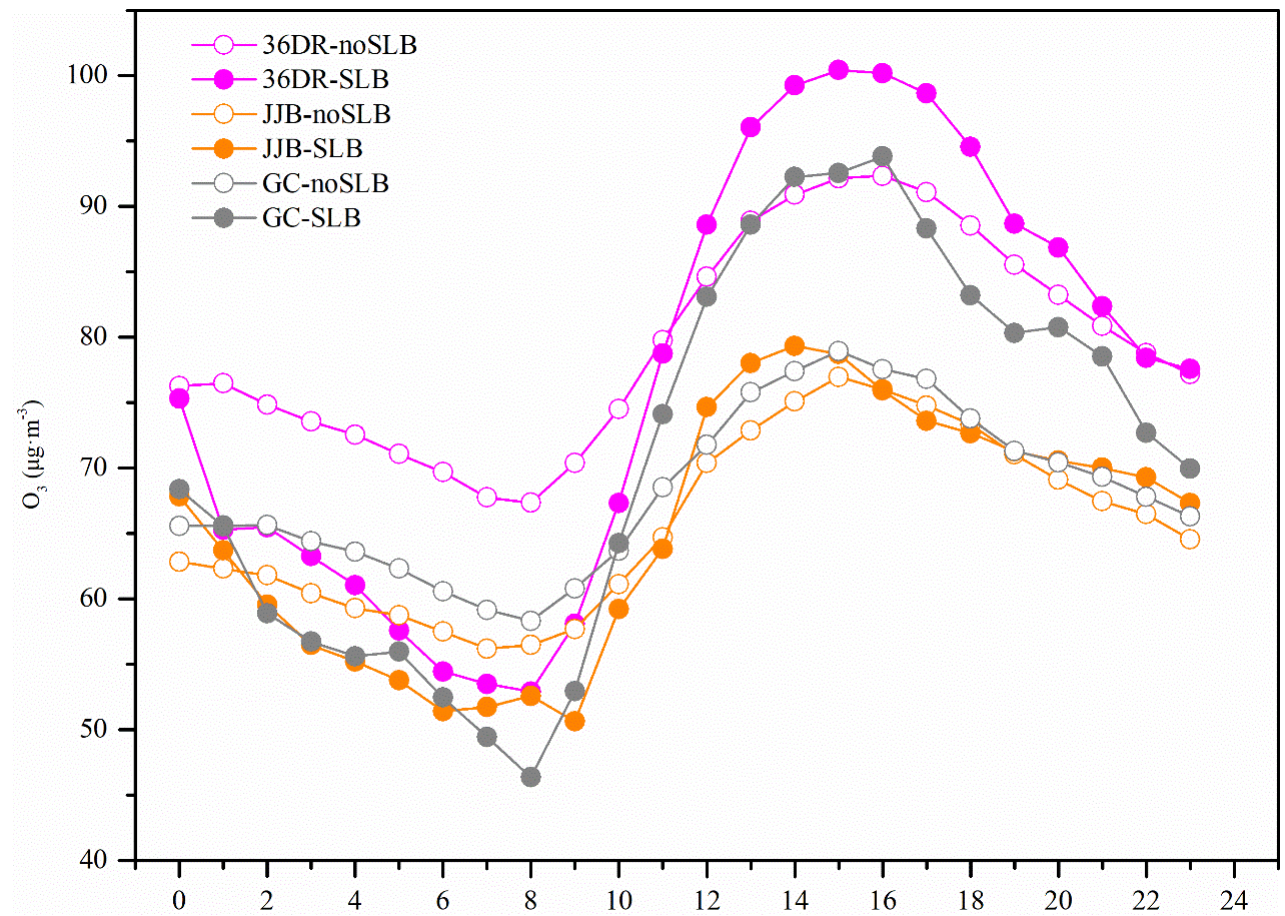

Fig. 4. Diurnal variations in $\mathrm{O}_{3}$ concentration at the three monitoring sites on days with and without SLBs.

\section{Effect of Regional Transport on $\mathrm{O}_{3}$ Concentration}

Wind speed in the study region is relatively high throughout the year because of the "narrow tube effect" in the Taiwan Strait. Since the influence of local pollutants in Pingtan is minimal, Pingtan is easily affected by long-distance transport. Fig. 5 shows the 72-h backward trajectory clusters along with the percentage contribution of each cluster to annual air masses. The mean $\mathrm{O}_{3}$ concentration of each trajectory cluster is also given. The trajectories in Pingtan were divided into six categories according to their 


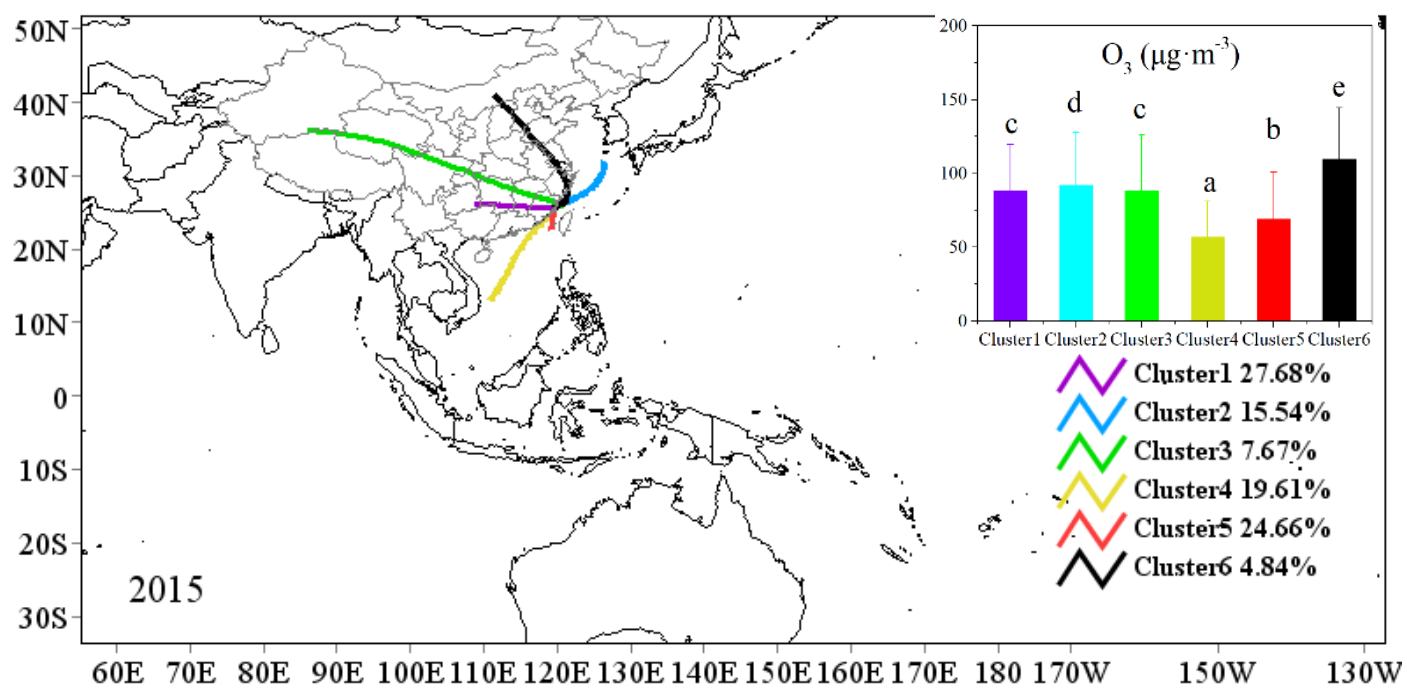

Fig. 5. Average backward trajectory clusters with the corresponding $\mathrm{O}_{3}$ concentrations at Pingtan in 2015.

origin and transport path: a continental mesoscale cluster (Cluster 1) from western China; a mesoscale northeastern marine cluster (Cluster 2) from northeastern China; a continental long-range cluster (Cluster 3 ) from northwestern China; a mesoscale southwestern marine cluster (Cluster 4) from the South China Sea; a short-range southern marine cluster (Cluster 5) originating from the Taiwan Strait; and a long-distance cluster (Cluster 6) from the North China Plain and passing over the YRD. The mesoscale westerly continental Cluster 1 was the largest contributor, accounting for $27.68 \%$ of all air masses, followed by Cluster $5(24.66 \%)$, Cluster 4 (19.61\%), Cluster 2 (15.44\%), Cluster $3(7.67 \%)$, and Cluster $6(4.84 \%)$.

Cluster 6 had the highest concentration of $\mathrm{O}_{3}(109.71$ $\mu \mathrm{g} \mathrm{m}^{-3}$ ), which might be associated with the high levels of primary pollutants in the surrounding industrial and densely populated areas (Cao et al., 2011). Cluster 4 from the South China Sea had the lowest $\mathrm{O}_{3}$ concentration $\left(56.73 \mu \mathrm{g} \mathrm{m}^{-3}\right)$ because it did not pass over any populated areas. Cluster 5 , the short-range southern marine cluster originating from the Taiwan Strait, had the second lowest of $\mathrm{O}_{3}$ concentration $\left(68.98 \mu \mathrm{g} \mathrm{m}^{-3}\right)$. Cluster 2, which originated from the East China Sea, had the second highest $\mathrm{O}_{3}$ concentration $\left(91.82 \mu \mathrm{g} \mathrm{m}^{-3}\right)$. The $\mathrm{O}_{3}$ concentrations of Cluster 3 from northwestern China and Cluster 1 from western China were similar (88.26 and $88.32 \mu \mathrm{g} \mathrm{m}^{-3}$, respectively).

Based on cluster analysis, we obtained six main transport pathways, demonstrating that $\mathrm{O}_{3}$ concentration was influenced by regional transport, especially from the surrounding industrial and densely populated areas.

\section{Effect of Regional Transport on $\mathrm{O}_{3}$ Episodes}

Cases of regional transport leading to $\mathrm{O}_{3}$ episodes are discussed in detail in this section. The calendar figure was used to identify instances when the $\mathrm{O}_{3}$ concentration at Pingtan exceeded the Chinese grade II level in 2015 based on the China GB 3095-2012 criteria. The $\mathrm{O}_{3}$ concentrations at the rural and suburban sites exceeded the grade II standard from October 12-14, 2015 (Fig. S3). Only the rural and suburban sites were selected for case study because of the lack of valid data for the urban site during that time period.

Fig. 6 presents the time series of hourly mean $\mathrm{O}_{3}$ concentration, relative humidity, temperature, and atmospheric pressure at the rural and suburban sites from October 10-17, 2015. From October 12-14, hourly $\mathrm{O}_{3}$ concentrations exceeding $200 \mu \mathrm{g} \mathrm{m}^{-3}$ were recorded at the rural site, and the concentrations at the rural site were always higher than those at the suburban site. The temperature and atmospheric pressures increased during the episode of increased $\mathrm{O}_{3}$ concentration (October 12-14), while the relative humidity was low. This indicates that high temperature, high atmospheric pressure, and low relative humidity promote $\mathrm{O}_{3}$ formation. $\mathrm{O}_{3}$ concentration was significantly positively correlated with the concentrations of other air pollutants (Table 3). Fig. 7 shows the $\mathrm{O}_{3}$ concentrations recorded on mainland China during the case study period. Before the episode in Pingtan, the $\mathrm{O}_{3}$ concentrations in most mainland cities were below the Chinese ambient air quality standard. Most cities on the southeastern coast suffered from light or moderate pollution from October 12-14, 2015. The pollution spread throughout eastern China from October 15-17, 2015. These results indicate that $\mathrm{O}_{3}$ pollution in Pingtan during this period was seriously affected by regional transport.

To determine the cause of the regional pollution, the weather patterns at the surface and $500 \mathrm{hPa}$ were obtained for October 10-17, 2015. Fig. 8 shows the climatological isolines and wind fields at the surface and at $500 \mathrm{hPa}$ over Pingtan from October 10-17, 2015. A semi-permanent, subtropical anticyclonic high-pressure system over the western North Pacific called the Western Pacific Subtropical High (WPSH) extends from the ground to the middle of the troposphere (Zhou et al., 2009). In 500-hPa weather patterns, the WPSH is usually indicated by an isoline at $5880 \mathrm{gpm}$ (Wang, 2006). In this study, the winds changed from southwesterly to northwesterly at $500 \mathrm{hPa}$. Approaching the surface, the WPSH shifted toward the northeast, driving a large amount of pollutants over Pingtan. During 

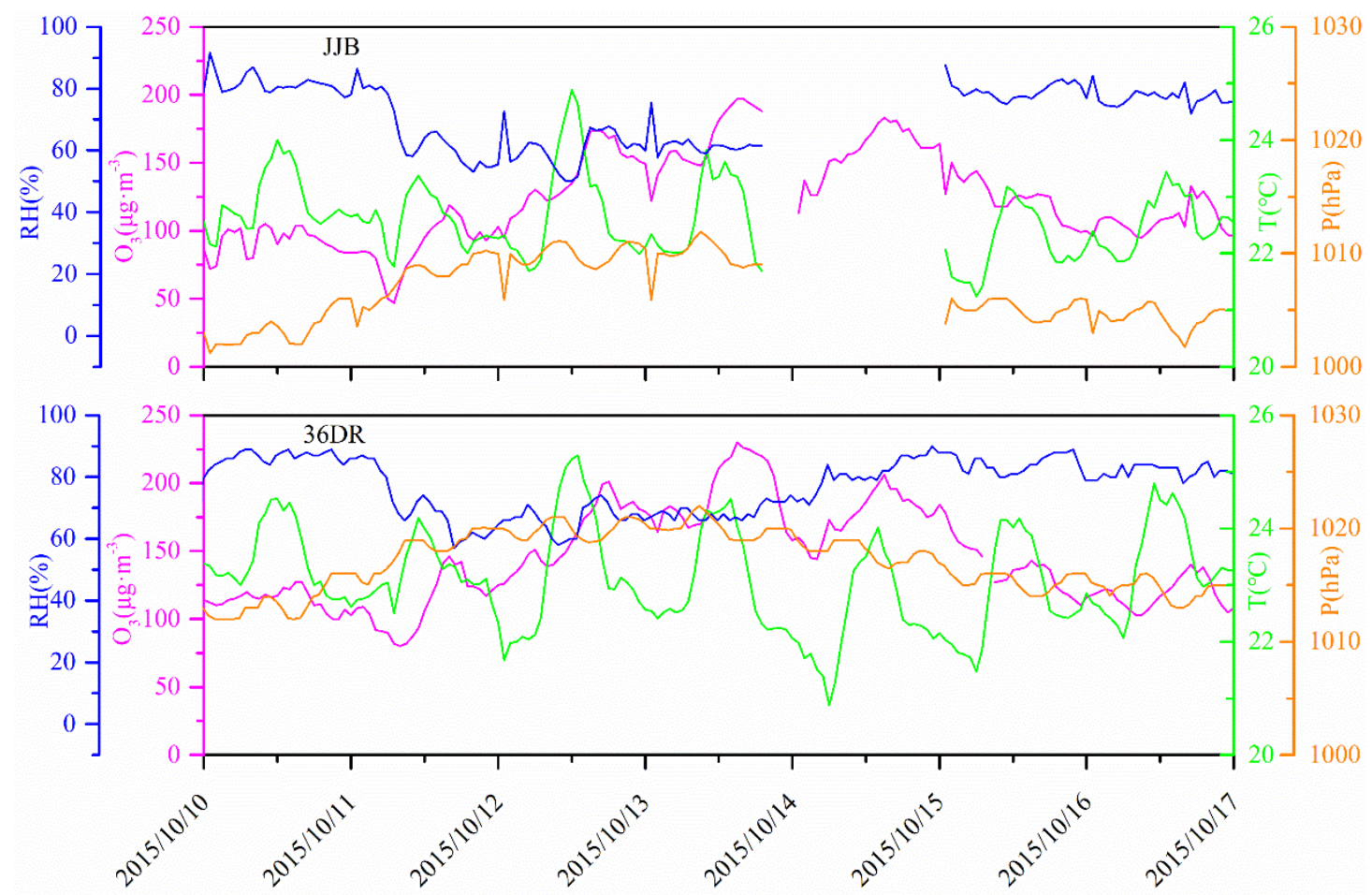

Fig. 6. Time series of hourly average $\mathrm{O}_{3}$ concentration, relatively humidity, temperature, and pressure at the rural and suburban Pingtan sites from October 10-17, 2015.

Table 3. Pearson correlation coefficients for the relationships between the concentrations of $\mathrm{O}_{3}$ and other pollutants from October 12-14, 2015.

\begin{tabular}{llllll}
\hline & $\mathrm{NO}_{2}$ & $\mathrm{CO}$ & $\mathrm{SO}_{2}$ & $\mathrm{PM}_{10}$ & $\mathrm{PM}_{2.5}$ \\
\hline Rural & $0.370^{* *}$ & $0.831^{* *}$ & $0.532^{* *}$ & $0.882^{* *}$ & $0.528^{* *}$ \\
Suburban & - & $0.854^{* *}$ & - & $0.854^{* *}$ & $0.943^{* *}$ \\
\hline
\end{tabular}

**: Significant correlation was found at the 0.01 level.

*: Significant correlation was found at the 0.05 level.

-: No valid data were available for correlation analysis.

the episode of high $\mathrm{O}_{3}$ concentration evaluated in the case study, all of Pingtan was under the control of a strong WPSH, which might have directly led to the abnormal high pressure observed in Fig. 8. The downdraft acted as a dome that trapped pollutants at the surface, and little convection occurred due to the lack of air lift. In addition, as the typhoon approached from October 14-17, the nearsurface wind speed over Pingtan gradually increased, mitigating the $\mathrm{O}_{3}$ pollution. Moreover, as the typhoon approached, the high-pressure system was compelled to disconnect and move southward. Finally, the high-pressure system was removed, and the $\mathrm{O}_{3}$ pollution was mitigated.

The spatial distributions of potential $\mathrm{O}_{3}$ sources and transport paths along with those of the precursor $\mathrm{CO}$ were determined for Pingtan by combining backward trajectories with the pollutant concentrations (Fig. 9). $\mathrm{CO}$ is an important $\mathrm{O}_{3}$ precursor emitted by anthropogenic activities. Furthermore, $\mathrm{CO}$ has a long lifetime (1-2 months) and can serve as an indicator for anthropogenic pollution in the study region (Pochanart et al., 1999). Thus, simultaneous measurements of $\mathrm{O}_{3}$ and $\mathrm{CO}$ provide an opportunity to study the anthropogenic effects on $\mathrm{O}_{3}$. Pochanart et al. (1999) continuously measured the $\mathrm{O}_{3}$ and $\mathrm{CO}$ concentrations on the Oki Islands to characterize the variation in $\mathrm{O}_{3}$ under the influence of the regional-scale anthropogenic emission of air pollutants in the northeast Asian Pacific rim region. Therefore, we evaluated the anthropogenic contribution to $\mathrm{O}_{3}$ pollution by simultaneously evaluating the PSCFs of $\mathrm{O}_{3}$ and $\mathrm{CO}$. The potential source locations were similar for $\mathrm{CO}$ and $\mathrm{O}_{3}$. The potential source regions with high PSCF values for $\mathrm{O}_{3}$ and $\mathrm{CO}$ were primarily distributed in the northwestern region of Pingtan. This indicates that $\mathrm{O}_{3}$ pollution in Pingtan largely originates from anthropogenic sources located in industrialized areas of the YRD. The industries that emit $\mathrm{O}_{3}$ precursors, such as $\mathrm{NO}_{\mathrm{x}}$ and VOCs, have important effects on the $\mathrm{O}_{3}$ concentration in Pingtan. Industrial sources of VOCs mainly include VOC production, storage, and transport; processes that use VOCs as raw materials; and the use of products containing VOCs (Liang, 2017). Industrial sources of $\mathrm{NO}_{\mathrm{x}}$ mainly include the non-metallic mineral products, steel, and biomedical manufacturing industries (Wu, 2009). 

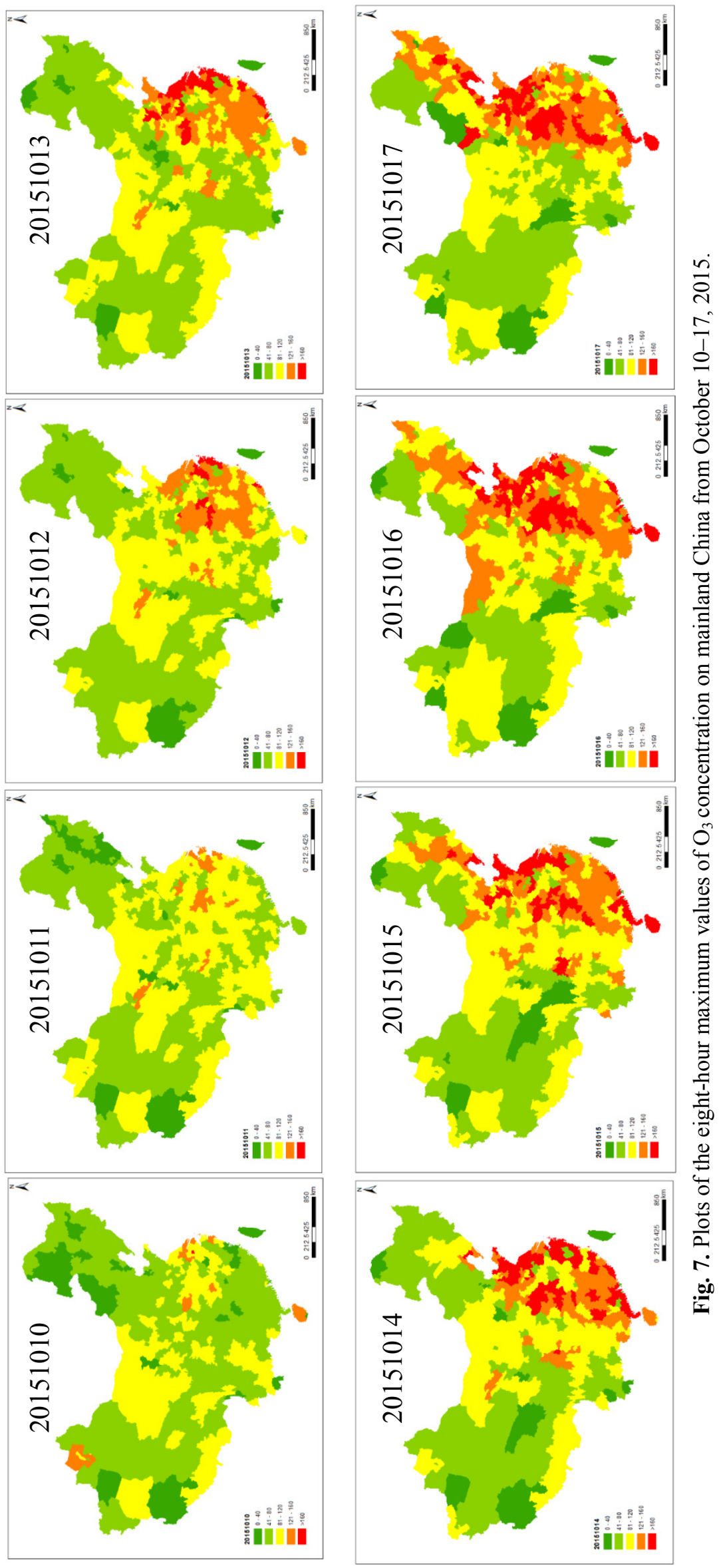

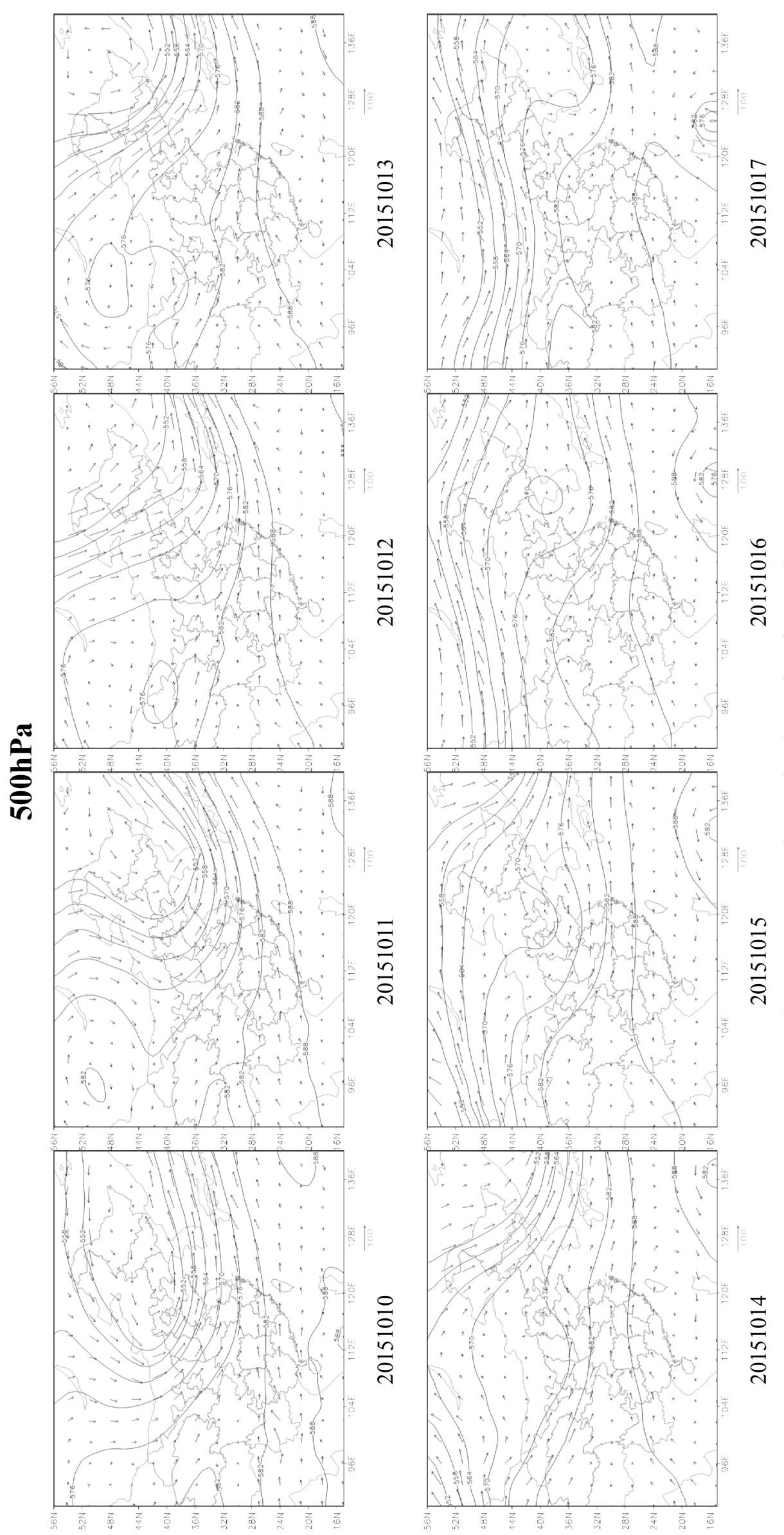

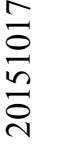

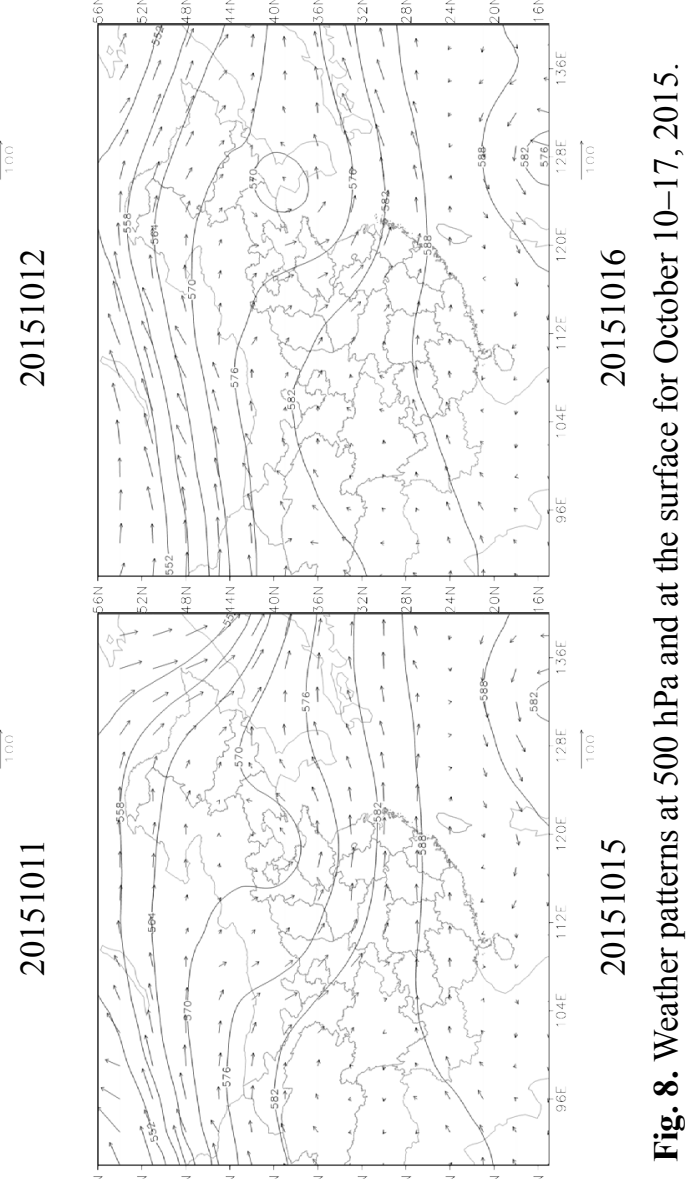




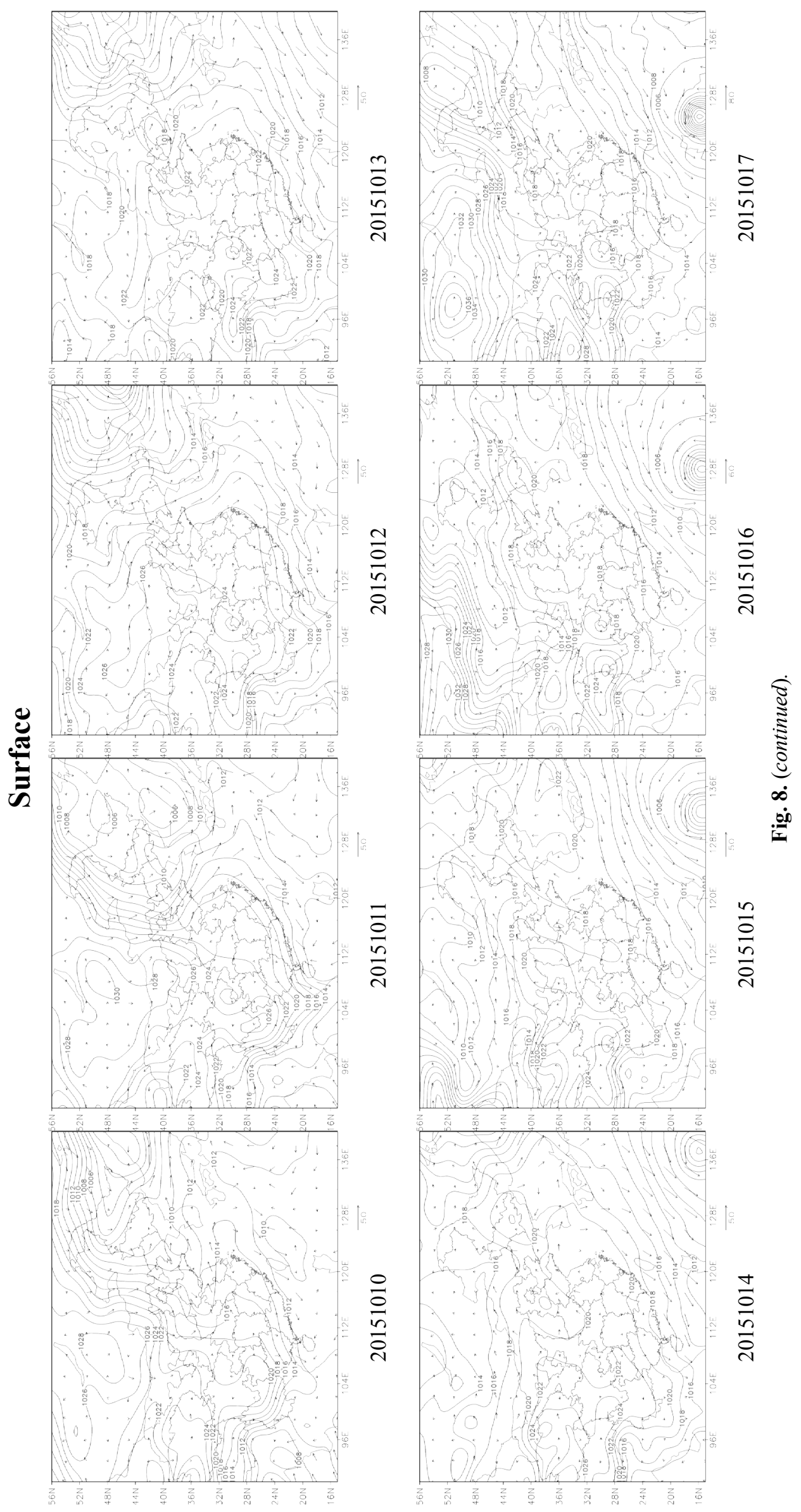



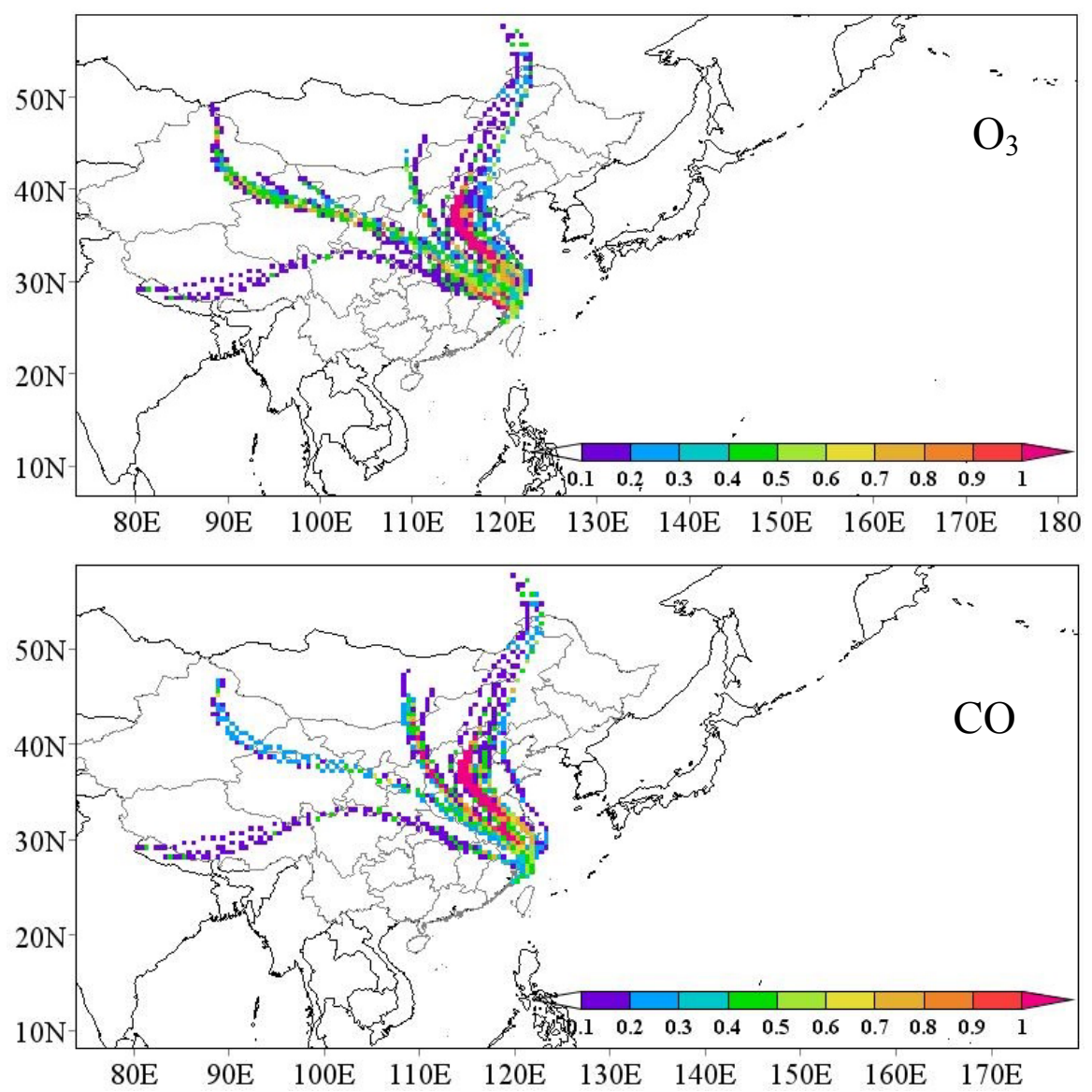

Fig. 9. Spatial distributions of PSCF for $\mathrm{O}_{3}$ and $\mathrm{CO}$ at Pingtan from October 10-17, 2015.

\section{CONCLUSION}

An island city under the control of the East Asian monsoon that is not strongly affected by anthropogenic sources of pollution was studied to evaluate the spatial and temporal variations in $\mathrm{O}_{3}$ concentration along with the effects of SLBs and regional transport. The minimum $\mathrm{O}_{3}$ concentrations measured at the rural $\left(65.60 \mu \mathrm{g} \mathrm{m}^{-3}\right)$, suburban $\left(55.77 \mu \mathrm{g} \mathrm{m}^{-3}\right)$, and urban sites $\left(55.53 \mu \mathrm{g} \mathrm{m}^{-3}\right)$ were higher than those reported in other cities, which was likely caused by low NO titration over Pingtan. The $\mathrm{O}_{3}$ concentrations at each site in summer, which should be high, were low due to the effect of the East Asian monsoon. SLBs increased the daily maximum $\mathrm{O}_{3}$ concentration at each site by approximately $10 \mu \mathrm{g} \mathrm{m}^{-3}$. The diurnal variation in $\mathrm{O}_{3}$ concentration was larger when SLBs was present compared to when SLBs was absent. Cluster analysis and the analysis of an episode of high $\mathrm{O}_{3}$ concentration indicated that $\mathrm{O}_{3}$ primarily originated from the transport of $\mathrm{O}_{3}$ precursors from the industrialized YRD region. These findings have implications for $\mathrm{O}_{3}$ pollution in similar areas.

\section{ACKNOWLEDGEMENTS}

This study was funded by the National Key Research and Development Program (2016YFC02005 \& 2016YFE0112200), the National Natural Science
Foundation of China (41575146), the Chinese Academy of Sciences Interdisciplinary Innovation Team Project, and the Natural Science Foundation of Fujian Province, China (2016J01201).

\section{SUPPLEMENTARY MATERIAL}

Supplementary data associated with this article can be found in the online version at http://www.aaqr.org.

\section{REFERENCES}

Adame, J.A., Hernández-Ceballos, M.Á., Sorribas, M., Lozano, A. and Benito Arturo De la, M. (2014). Weekend-weekday effect assessment for $\mathrm{O}_{3}, \mathrm{NO}_{\mathrm{x}}, \mathrm{CO}$ and $\mathrm{PM}_{10}$ in Andalusia, Spain (2003-2008). Aerosol Air Qual. Res. 14: 1862-1874.

Banan, N., Latif, M.T., Juneng, L. and Ahamad, F. (2013). Characteristics of surface ozone concentrations at stations with different backgrounds in the Malaysian Peninsula. Aerosol Air Qual. Res. 13: 1090-1106.

Bei, N., Zhao, L., Wu, J., Li, X., Feng, T. and Li, G. (2018). Impacts of sea-land and mountain-valley circulations on the air pollution in Beijing-Tianjin-Hebei (BTH): A case study. Environ. Pollut. 234: 429-438.

Cao, G., Zhang, X., Gong, S., An, X. and Wang, Y. (2011). Emission inventories of primary particles and pollutant 
gases for China. Chin. Sci. Bull. 56: 781-788.

Chou, C.C.K., Liu, S.C., Lin, C.Y., Shiu, C.J. and Chang, K.H. (2006). The trend of surface ozone in Taipei, Taiwan, and its causes: Implications for ozone control strategies. Atmos. Environ. 40: 3898-3908.

Darby, L.S., McKeen, S.A., Senff, C.J., White, A.B., Banta, R.M., Post, M.J., Brewer, W.A., Marchbanks, R., Alvarez, R.J., Peckham, S.E., Mao, H. and Talbot, R. (2007). Ozone differences between near-coastal and offshore sites in New England: Role of meteorology. $J$. Geophys. Res. 112: D16S91.

Ding, A., Wang, T., Zhao, M., Wang, T. and Li, Z. (2004). Simulation of sea-land breezes and a discussion of their implications on the transport of air pollution during a multi-day ozone episode in the Pearl River Delta of China. Atmos. Environ. 38: 6737-6750.

Duncan, B.N., Lamsal, L.N., Thompson, A.M., Yoshida, Y., Lu, Z., Streets, D.G., Hurwitz, M.M. and Pickering, K.E. (2015). A space-based, high-resolution view of notable changes in urban $\mathrm{NO}_{\mathrm{x}}$ pollution around the world (2005-2014). J. Geophys. Res. 121: 976-996.

Eva, H. and Lambin, E.F. (1998). Remote sensing of biomass burning in tropical regions: Sampling issues and multisensor approach. Remote Sens. Environ. 64: 292-315.

Gao, W., Tie, X., Xu, J., Huang, R., Mao, X., Zhou, G. and Chang, L. (2017). Long-term trend of $\mathrm{O}_{3}$ in a mega city (Shanghai), China: Characteristics, causes, and interactions with precursors. Sci. Total Environ. 603-604: 425-433.

Gong, X., Hong, S. and Jaffe, D.A. (2018). Ozone in China: Spatial distribution and leading meteorological factors controlling $\mathrm{O}_{3}$ in 16 Chinese cities. Aerosol Air Qual. Res. 18: 2287-2300.

Hassan, I.A., Basahi, J.M., Ismail, I.M. and Habeebullah, T.M. (2013). Spatial distribution and temporal variation in ambient ozone and its associated $\mathrm{NO}_{\mathrm{x}}$ in the atmosphere of Jeddah city, Saudi Arabia. Aerosol Air Qual. Res. 13: 1712-1722.

Hopke, P.K., Barrie, L.A., Li, S.M., Cheng, M.D., Li, C. and Xie, Y. (1995). Possible sources and preferred pathways for biogenic and non-sea salt sulfur for the high Arctic. J. Geophys. Res. 100: 16595-16603.

Hsu, C.H. and Cheng, F.Y. (2019). Synoptic weather patterns and associated air pollution in Taiwan. Aerosol Air Qual. Res. 19: 1139-1151.

Jo, W.K. and Park, J.H. (2005). Characteristics of roadside air pollution in Korean metropolitan city (Daegu) over last 5 to 6 years: Temporal variations, standard exceedances, and dependence on meteorological conditions. Chemosphere 59: 1557-1573.

Khoder, M.I. (2009). Diurnal, seasonal and weekdaysweekends variations of ground level ozone concentrations in an urban area in greater Cairo. Environ. Monit. Assess. 149: 349-362.

Kiros, F., Shakya, K.M., Rupakheti, M., Regmi, R.P., Maharjan, R., Byanju, R.M., Naja, M., Mahata, K., Kathayat, B. and Peltier, R.E. (2017). Variability of anthropogenic gases: Nitrogen oxides, sulfur dioxide, ozone and ammonia in Kathmandu valley, Nepal.
Aerosol Air Qual. Res. 17: 3088-3101.

Kulkarni, P.S., Bortoli, D., Domingue, A. and Silva, A.M. (2017). Surface ozone variability and trend over urban and suburban sites in Portugal. Aerosol Air Qual. Res. 17: $138-152$.

Kumar, A., Singh, D., Singh, B.P., Singh, M., Anandam, K., Kumar, K. and Jain, V.K. (2014). Spatial and temporal variability of surface ozone and nitrogen oxides in urban and rural ambient air of Delhi-NCR, India. Air Qual. Atmos. Health 8: 391-399.

Lal, S., Venkataramani, S., Naja, M., Kuniyal, J.C., Mandal, T.K., Bhuyan, P.K., Kumari, K.M., Tripathi, S.N., Sarkar, U., Das, T., Swamy, Y.V., Gopal, K.R., Gadhavi, H. and Kumar, M.K.S. (2017). Loss of crop yields in India due to surface ozone: An estimation based on a network of observations. Environ. Sci. Pollut. Res. Int. 24: 20972-20981.

Latif, M.T., Huey, L.S. and Juneng, L. (2012). Variations of surface ozone concentration across the Klang valley, Malaysia. Atmos. Environ. 61: 434-445.

Liang, X. (2017). Reactivity-based anthropogenic volatile organic compounds emission inventory and $\mathrm{O}_{3}$ control strategies in China, South China University of Technology.

Lin, M., Horowitz, L.W., Payton, R., Fiore, A.M. and Tonnesen, G. (2017). US surface ozone trends and extremes from 1980 to 2014: quantifying the roles of rising Asian emissions, domestic controls, wildfires, and climate. Atmos. Chem. Phys. 17: 2943-2970.

Lu, X., Chow, K.C., Yao, T., Fung, J.C.H. and Lau, A.K.H. (2009). Seasonal variation of the land-sea breeze circulation in the Pearl River Delta region. J. Geophys. Res. 114: D17112.

Monks, P.S. (2000). A review of the observations and origins of the spring ozone maximum. Atmos. Environ. 34: 3545-3561.

NRC (1991). Committee on tropospheric ozone formation and measurement. In Rethinking the ozone problem in urban and regional air pollution. National Academy Press.

Pochanart, P., Hirokawa, J., Kajii, Y., Akimoto, H. and Nakao, M. (1999). Influence of regional-scale anthropogenic activity in northeast Asia on seasonal variations of surface ozone and carbon monoxide observed at Oki, Japan. J. Geophys. Res. 104: 3621-3631.

Polissar, A.V., Hopke, P.K., Paatero, P., Kaufmann, Y.J., Hall, D.K., Bodhaine, B.A., Dutton, E.G. and Harris, J.M. (1999). The aerosol at Barrow, Alaska: Long-term trends and source locations. Atmos. Environ. 33: 24412458.

Reddy, B.S.K., Kumar, K.R., Balakrishnaiah, G., Gopal, K.R., Reddy, R.R., Sivakumar, V., Lingaswamy, A.P., Arafath, S.M., Umadevi, K., Kumari, S.P., Ahammed, Y.N. and Lal, S. (2012). Analysis of diurnal and seasonal behavior of surface ozone and its precursors $\left(\mathrm{NO}_{\mathrm{x}}\right)$ at a semi-arid rural site in southern India. Aerosol Air Qual. Res. 12: 1081-1094.

Roberts-Semple, D., Song, F. and Gao, Y. (2012). Seasonal characteristics of ambient nitrogen oxides and ground- 
level ozone in metropolitan northeastern New Jersey. Atmos. Pollut. Res. 3: 247-257.

Rolph, G.D. (2003). Real-time environmental applications and display system (ready) website. NOAA Air Resources Laboratory, Silver Spring, MD, http://www.arl.noaa.gov/ ready/hysplit4.html, Last Access: 31 December 2018.

Romesburg, H.C. (1984). Cluster analysis for researchers. Lifetime Learning Publications, Belmont, Calif.

Simon, H., Reff, A., Wells, B., Xing, J. and Frank, N. (2015). Ozone trends across the united states over a period of decreasing $\mathrm{NO}_{\mathrm{x}}$ and VOC emissions. Environ. Sci. Technol. 49: 186-195.

Stauffer, R.M., Thompson, A.M., Martins, D.K., Clark, R.D., Goldberg, D.L., Loughner, C.P., Delgado, R., Dickerson, R.R., Stehr, J.W. and Tzortziou, M.A. (2015). Bay breeze influence on surface ozone at Edgewood, MD during july 2011. J. Atmos. Chem. 72: 335-353.

Stunder, B.J.B. (1996). An assessment of the quality of forecast trajectories J. Appl. Meteorol. 35: 1319-1331.

Tong, L., Zhang, H., Yu, J., He, M., Xu, N., Zhang, J., Qian, F., Feng, J. and Xiao, H. (2017). Characteristics of surface ozone and nitrogen oxides at urban, suburban and rural sites in Ningbo, China. Atmos. Res. 187: 57-68.

Tong, L., Zhang, J., Xu, H., Xiao, H., He, M. and Zhang, H. (2018). Contribution of regional transport to surface ozone at an island site of Eastern China. Aerosol Air Qual. Res. 18: 3009-3024.

Tu, J., Xia, Z.G., Wang, H. and Li, W. (2007). Temporal variations in surface ozone and its precursors and meteorological effects at an urban site in China. Atmos. Res. 85: 310-337.

Vellingiri, K., Kim, K.H., Lim, J.M., Lee, J.H., Ma, C.J., Jeon, B.H., Sohn, J.R., Kumar, P. and Kang, C.H. (2016). Identification of nitrogen dioxide and ozone source regions for an urban area in Korea using back trajectory analysis. Atmos. Res. 176-177: 212-221.

Wagner, N.L., Riedel, T.P., Roberts, J.M., Thornton, J.A., Angevine, W.M., Williams, E.J., Lerner, B.M., Vlasenko, A., Li, S.M., Dubé, W.P., Coffman, D.J., Bon, D.M., de Gouw, J.A., Kuster, W.C., Gilman, J.B. and Brown, S.S. (2012). The sea breeze/land breeze circulation in Los Angeles and its influence on nitryl chloride production in this region. J. Geophys. Res. 117: D00V24.

Wang, H., Jiang, D., Xie, Z., Zheng, Q. and Yang, Y.
(2018). The spatial and temporal distribution and synoptic causes of surface layer ozone in Fujian province. MidLow Latitude Mt. Meteorol. 42: 1-6. (in Chinese)

Wang, H., Lyu, X., Guo, H., Wang, Y., Zou, S., Ling, Z., Wang, X., Jiang, F., Zeren, Y., Pan, W., Huang, X. and Shen, J. (2018). Ozone pollution around a coastal region of South China Sea: Interaction between marine and continental air. Atmos. Chem. Phys. 18: 4277-4295.

Wang, L., Guan, H. and He, J. (2006). The position variation of thewest pacific subtropical high and its possible mechanism. J. Trop. Meteorol. 12: 113-120.

Wang, T., Xue, L., Brimblecombe, P., Lam, Y.F., Li, L. and Zhang, L. (2017). Ozone pollution in China: A review of concentrations, meteorological influences, chemical precursors, and effects. Sci. Total Environ. 575: 15821596.

Wu, X. (2009). The study of air pollution emission inventory in Yangtze Delta, FuDan University, China.

Xu, J., Ma, J.Z., Zhang, X.L., Xu, X.B., Xu, X.F., Lin, W.L., Wang, Y., Meng, W. and Ma, Z.Q. (2011). Measurements of ozone and its precursors in Beijing during summertime: Impact of urban plumes on ozone pollution in downwind rural areas. Atmos.Chem. Phys. 11: 12241-12252.

Zhang, Y., Cooper, O.R., Gaudel, A., Thompson, A.M., Nédélec, P., Ogino, S.Y. and West, J.J. (2016). Tropospheric ozone change from 1980 to 2010 dominated by equatorward redistribution of emissions. Nat. Geosci. 9: 875-879.

Zheng, J., Zhong, L., Wang, T., Louie, P.K.K. and Li, Z. (2010). Ground-level ozone in the Pearl River Delta region: Analysis of data from a recently established regional air quality monitoring network. Atmos. Environ. 44: 814-823.

Zhou, T., Yu, R., Zhang, J., Drange, H., Cassou, C., Deser, C., Hodson, D.L.R., Sanchez-Gomez, E., Li, J., Keenlyside, N., Xin, X. and Okumura, Y. (2009). Why the western pacific subtropical high has extended westward since the late 1970s. J. Clim. 22: 2199-2215.

Received for review, April 9, 2019 Revised, July 10, 2019 Accepted, July 16, 2019 